\title{
Pengembangan Media Interaktif Berbasis Ispring Materi Sistem Pencernaan Manusia Kelas V Di SDN Ciptomulyo 3 Kota Malang
}

\author{
Nury Yuniasih ${ }^{1}$, Ririn Nur Aini ${ }^{2}$, Retno Widowati ${ }^{3}$ \\ Pendidkan Guru Sekolah Dasar Universitas Kanjuruhan Malang \\ nuryyuniasih@unikama.ac.id \\ Ririnnur0@gmail.com
}

\begin{abstract}
Abstrak
Perkembangan teknologi yang semakin mempengaruhi tingkah laku manusia, mulai dari cara berkomunikasi hingga cara mengajar di kelas. Realitanya masih banyak guru yang kesulitan menggunakan teknologi, menjadikan pembelajaran kurang dapat mengkonkretkan materi. Tujuan dari penelitian ini adalah 1) mengembangkan media interaktif berasis Ispring, 2) mendeskripsikan kelayakan dari media interaktif berbasis Ispring, 3) mendeskripsikan kepraktisan media interaktif berbasis Ispring. Metode yang digunakan mengadaptasi dari model ADDIE dengan empat tahapan yaitu: analisis, desain, pengembangan dan implementasi. Subjek uji coba adalah siswa kelas V SDN Ciptomulyo 3. Instrumen pengumpulan data menggunakan angket, wawancara tidak terstruktur, dan dokumentasi. Hasil penelitian menunjukkan bahwa media interaktif layak untuk digunakan. Penilaian oleh ahli media mendapatkan presentase $85 \%$. Penilaian oleh ahli materi mendapatkan presentase $94 \%$. Penilaian oleh calon pengguna mendapatkan presentase $93 \%$. Penilaian hasil respon siswa pada ujicoba lapangan terbatas mendapatkan presentase $93 \%$. Berdasarkan paparan hasil penilaian tersebut, media interaktif "Layak" atau "Sangat Baik" untuk digunakan sebagai media pembelajaran.
\end{abstract}

Kata Kunci: Media Interaktif, Sistem Pencernaan Manusia, Ispring.

\begin{abstract}
Technological developments that increasingly affect human behavior, ranging from how to communicate to how to teach in class. The reality is that there are still many teachers who have difficulty using technology, making learning less able to concretize the material. The purpose of this research is 1) developing Ispringbased interactive media, 2) describing the feasibility of Ispring-based interactive media, 3) describing the practicality of Ispring-based interactive media. The method used adapted from the ADDIE model with four stages: analysis, design, development and implementation. The test subjects were the fifth grade students of Ciptomulyo Elementary School 3. Data collection instruments used questionnaires, unstructured interviews, and documentation. The results of the study show that interactive media is suitable for use. Assessment by media experts gets a percentage of $85 \%$. Assessment by material experts received a percentage of $94 \%$. Assessment by prospective users gets a percentage of 93\%. Assessment of student response results in limited field trials received a percentage of 93\%. Based on the results of the assessment, interactive media is "Decent" or "Very Good" to be used as learning media.
\end{abstract}

keyword: Interactive Media, Human Digestive System, Ispring

\section{PENDAHULUAN}

Perkembangan teknologi informasi dan komunikasi memiliki pengaruh besar terhadap dunia pendidikan. Guru dapat memberikan layanan pendidikan melalui teknologi meliputi telepon, komputer, internet, maupun email.
Penggunaan teknologi menyebabkan pembelajaran yang diberikan guru tidak monoton tatap muka di sekolah. Suyanto, (2013:176) menyatakan hal tersebut didukung dengan munculnya fenomena pengajaran maya atau cyber teaching yaitu proses pengajaran 
yang dilakukan dengan menggunakan internet. Bentuk pengajaran maya tersebut berupa $e$ learning, e-mail.

Agustin (2011:102) menyatakan teknologi dalam pendidikan memiliki dampak besar terhadap keluaran pembelajaran. Penggunaan teknologi dalam pembelajaran dapat mengatasi keterbatasan ruang dan waktu, menyebarkan informasi lebih luas, cepat, sehingga pesan dapat disampaikan sesua tujuan pembelajaran.

Menurut Prastowo (2011:18) realita pendidikan di lapangan masih banyak guru yang menggunakan bahan ajar konvensional. Bahan ajar konvensional berupa bahan ajar yang tinggal pakai, kemungkinan kecil dalam merencanakan sendiri. Bahan ajar seperti ini didapatkan guru dari pemerintah, sehingga hanya sebagian kecil yang menambahi materi ajar dari buku lain untuk menunjang keterbatasan materi yang tersedia. Penggunaan bahan ajar tanpa dibantu dengan media atau teknologi dalam pembelajaran akan menyulitkan siswa dalam memahami materi yang abstrak.

Secara garis besar, masih banyak guru yang kesulitan memanfaatkan teknologi. Darmawan (2015:94) mengatakan realita yang ada sejumlah guru tidak memiliki kemampuan menggunakan teknologi, ada guru yang tidak memiliki pengetahuan tentang penggunaan komputer, dan ada guru yang memiliki kemampuan menggunakan komputer tetapi tidak dapat memanfaatkan internet. Pelatihan maupun seminar diperlukan untuk membantu guru agar dapat memanfaatkan teknologi dalam pembelajaran di kelas.

Penggunaan teknologi dalam

pembelajaran dapat menggunakan CD-ROM, dan internet. CD-ROM dapat digunakan sebagai alat penyimpanan media pembelajaran yang berisi konten bervariasi dan mudah didapat. Penggunaanm teknologi internet dalam pembelajaran dapat dilakukan siswa dan guru untuk mencari materi, gambar maupun video yang mendukung proses pembelajaran. Hal ini dapat dilakukan menggunakan gadget maupun komputer di sekolah. Rizema Putra (2012:207) mengatakan bahwa aktifitas dan fasilitas yang dapat digunakan dalam pembelajaran yaitu email, web browsing, chat room. Darmawan (2015:133) menambahkan bahwa penggunaan teknologi sebagai media dapat membantu siswa lebih tertarik dalam belajar, media yang berisi video, audio, animasi, memberikan pemahaman yang utuh kepada siswa.

Menurut Rusman (2011:170) media pembelajaran merupakan alat pembawa pesan yang dapat digunakan untuk keperluan pembelajaran. Gafur (2012:103-104) mengatakan bahwa media pembelajaran adalah komponen penting dalam perencanaan, pelaksanaan, dan evaluasi pembelajaran. Banyak media pembelajaran yang dapat digunakan, tetapi sebelum menggunakan media harus melihat terlebih dahulu kondisi kebutuhan siswanya, agar media dapat terealisasikan secara optimal. 
Manfaat media pembelajaran menurut Indriana (2011:48-49) meliputi: a) membuat konkret berbagai konsep yang abstrak, b) menghadirkan berbagai objek yang sulit didapat sekitar lingkungan, misalnya penggunaan foto, $\mathrm{CD}$, video, atau televisi untuk memberikan informasi binatang buas seperti harimau, c) menampilkan objek yang terlalu besar atau kecil ke dalam kelas misalnya, pesawat, kapal, virus, bakteri dan sebagainya, d) memperlihatkan gerakan yang terlalu cepat aatau lambat, tahapan terlalu lambat berupa tahapan perkembangan benih, proses mekarnyaa bunga dapat dipercepat prosesnya dalam bentuk video.

Fathurrohman (2014:67) menyatakan bahwa media pembelajaran ada tiga bentuk meliputi: a) media audio, media yang hanya mengandalkan kemampuan suara saja seperti radio, cassete recorder, piringan hitam, b) media visual, media yang hanya mengandalkan indera penglihatan dapat menampilkan gambar, film bisu, film kartun, c) media audio visual, media yang mempunyai unsur suara dan gambar misalnya televisi dan CD pembelajaran.

Susanto (2013:170) menyatakan bahwa pembelajaran IPA merupakan pembelajaran yang menumbuhkan sikap ilmiah tahapan konsep IPA. Pembelajaran IPA untuk anak sekolah dasar menekankan pada pemberian pengalaman belajar secara langsung dan konkret dengan media pembelajaran yang inovatif dapat menunjang daya berfikir siswa.

Secara garis besar, disetiap sekolah telah memiliki fasilitas yang memadai sesuai perkembangan teknologi seperti adanya LCD untuk mendukung proses pembelajaran. SDN Ciptomulyo 3 memiliki fasilitas LCD yang telah merata disetiap kelas. penggunaan LCD biasanya digunakan untuk menampilkan video dan gambar sebagai media pembelajaran. Proses pembelajaran masih menggunakan metode ceramah yang membuat siswa tidak aktif. Media pembelajaran yang guru tampilkan belum didesain menarik menggunakan teknologi seperti aplikasi yang telah berkembang saat ini.

Terutama untuk materi sistem pencernaan manusia media pembelajaran harus dibuat konkret agar siswa memahami dengan detail tahapan sistem pencernaan yang terjadi pada tubuh manusia. Pembelajaran materi sistem pencernaan manusia siswa dituntut untuk menghafal yang membuat siswa kesulitan. Realitanya sebagian siswa masih mengalami kesalahan dalam menyebutkan tahapan proses pencernaan, karena guru belum menggunakan media yang mendukung materi sistem pencernaan sesuai kebutuhan siswa. Media pembelajaran yang berinovasi dibutuhkan untuk mendukung materi ini. Pemanfaatan media pembelajaran berbasis komputer dapat dijadikan solusi agar siswa lebih tertarik dalam belajar dan tidak merasa kesulitan untuk memahami serta mengingatnya.

Sanjaya (2012:219) menyatakan pembelajaran multimedia merupakan pembelajaran yang didesain dengan menggunakan berbagai media secara bersamaan seperti teks, gambar, video, saling berhubungan 
untuk mencapai tujuan pembelajaran. Winarno (2009:7) mengatakan bahwa multimedia adalah kombinasi beberapa media seperti teks, suara, animasi, dan video yang disampaikan manusia melalui computer atau peralatan manipulasi elektronik. Berdasarkan kedua pendapat tersebut dapat disimpulkan bahwa pembelajaran multimedia cara mengoperasikannya melalui computer yang terdiri dari gambar, video dan audio dapat dijalankan secara bersama-sama. Pembuatan media dengan memanfaatkan multimedia dapat dengan penggunaan aplikasi seperti aplikasi presentasi yaitu Microsoft Powerpoint.

Media pembelajaran sangat beragam seiring perkembangan teknologi dan komunikasi. Pembuatan media pembelajaran dapat menggunakan Microsoft Powerpoint yang merupakan salah satu program Microsoft Office sebagai alat presentasi. Penggunaan Microsoft Powerpoint membantu untuk menggabungkan animasi, gambar, video, audio, sehingga dapat didesain menjadi media yang menarik.

Rusman (2012:301) menyatakan bahwa Microsoft Powerpoint merupakan salah satu bentuk software yang dirancang untuk menampilkan program multimedia dengan menarik, mudah dalam penggunaan dan relatif murah. Relatif murah karena merupakan aplikasi bawaan dari Microsoft Office yang telah terinstal bersamaan dengan menginstal windows.

Kelemahan Microsoft Powerpoint, file video maupun audio yang terdapat pada
Microsoft Powerpoint harus dijadikan satu folder dengan file presentasi Powerpoint agar dapat berjalan maksimal, jika pada folder yang berbeda akan membuat video maupun audio tidak berjalan atau tidak dapat dimainkan. Hal ini menyebabkan, harus keluar dari lembar kerja Microsoft Powerpoint untuk membuka file video dan audio. Kelemahan tersebut perlu dipadukan dengan aplikasi lain seperti aplikasi Ispring yang Add-Ins langsung dalam aplikasi Powerpoint. Aplikasi Ispring dapat membuat file presentasi menjadi flash dengan mudah dan membuat video yang dimasukkan dapat berjalan lancar. Pemanfaatan aplikasi Ispring dapat mempermudah guru untuk mengajarkan materi yang abstrak menjadi konkret tepatnya pada materi sistem pencernaan manusia. Pembelajaran menggunakan media ini dapat membantu siswa untuk lebih mudah memahami materi dan menjadikan pembelajaran lebih menarik.

Menurut Hermawati (2010:1 ) Ispring merupakan salah satu tool yang mengubah file presentasi menjadi bentuk flash, secara mudah dapat diintegrasikan dalam Microsoft Powerpoint sehingga penggunaannya tidak membutuhkan keahlian yang rumit. Penggunaan aplikasi ini dapat membuat berbagai bentuk quiz, memasukkan audio, video, maupun youtobe.

Berdasarkan paparan di atas, tujuan penelitian ini antara lain 1) untuk mengembangkan media interaktif berbasis Ispring materi sistem pencernaan manusia kelas 
V di Sdn Ciptomulyo 3 Kota Malang. 2) untuk mengetahui kelayakan media interaktif berbasis Ispring materi sistem pencernaan manusia kelas V di Sdn Ciptomulyo 3 Kota Malang. 3) untuk mengetahui kepraktisan penggunaan media interaktif berbasis Ispring materi sistem pencernaan manusia kelas V di Sdn Ciptomulyo 3 Kota Malang.

\section{METODE}

\section{PENGEMBANGAN}

Penelitian ini menggunakan jenis penelitian pengembangan yang mengadaptasi model pengembangan ADDIE. Tahapan yang harus dilakukan peneliti meliputi analisis, desain, pengembangan, dan implementasi.

Menurut Gafur (2012:38) dalam bukunya meyatakan bahwa tahapan pada model pengembangan ADDIE dapat dijabarkan sebagai berikut:

a. Tahap analisis ada 4 hal yang harus dipertimbangkan yaitu menganalisis kurikulum yang digunakan oleh sekolah, menganalisis karakteristik guru, analisis karateristik siswa, dan pemanfaatan media.

b. Tahap desain meliputi menentukan materi pembelajaran, media, evaluasi, dan sumber belajar.

c. Tahap pengembangan yang harus dilakukan adalah memproduksi media sesuai desain dan merevisi media pada ahli materi maupun ahli media. d. Tahap implementasi, dilakukan ujicoba untuk mengetahui ketercapaian media yang dirancang pada guru dan siswa.

Pengembangan media interaktif berbasis Ispring Suite 8.0 mengunakan materi sistem pencernaan manusia kelas V semester 1. Materi tersebut terdapat pada Tema 3 Subtema 1 Pembelajaran ke-5. Media interaktif ini dibuat untuk membantu proses pembelajaran agar lebih konkret berisi video, audio, materi, animasi, maupun gambar.

Pengembangan produk awal yang telah dibuat harus melalui tahap validasi dengan melibatkan ahli media dan ahli materi. Tujuan dari uji validasi untuk mengetahui kekurangan dari media interaktif sebagai pedoman perbaikan. Produk yang melalui tahap validasi dan valid, maka media layak atau siap diujicobakan kepada guru kelas sebagai calon pengguna.

Uji coba produk dilakukan melalui uji lapangan terbatas dengan memberikan angket kepada 15 siswa SDN Ciptomulyo 3. Uji coba kepada guru kelas V dilakukan terlebih dahulu sebelum uji lapangan terbatas sampai media dinyatakan baik untuk siswa. Subjek uji coba kepada ahli media dilakukan pada dosen yang ahli pada bidang media dan aplikasi. Subjek uji coba ahli materi dilakukan kepada dosen yang mengajar Ilmu Pengetahuan Alam SD. Subjek uji coba calon pengguna yaitu guru kelas V, sedangkan siswa diambil 15 orang di SDN Ciptomulyo 3. Penelitian dilakukan pada tahun 
JIP, Vol.8, No. 2, Edisi Agustus 2018, Hal: 85-94

Nury Yuniasih ${ }^{1}$, Ririn Nur Aini ${ }^{2}$, Retno Widowati ${ }^{3}$

ajaran 2017/2018 semester genap bertempat SDN Ciptomulyo 3 Kota Malang.

Jenis data yang digunakan dalam penelitian ini yaitu data kualitatif dan kuantitatif. Widoyoko (2013:21) mengatakan data kualitatif adalah data yang menunjukkan kualitas yang dinyatakan dalam bentuk pernyataan sedangkan data kuantitatif adalah data berwujud angka-angka sebagai hasil pengukuran.

Instrumen pengumpulan data meliputi angket, dokumentasi, dan wawancara. Sugiyono (2010:199) mengatakan bahwa teknik pengumpulan data bentuk angket dilakukan dengan cara memberikan seperangrangkat pertanyaan atau pernyataan kepada responden. Wawancara yang dilakukan oleh peneliti adalah wawancara tidak terstruktur. Sugiyono (2012:188-189) wawancara tidak terstruktur dilakukan tanpa menggunakan pedoman wawancara yang tersusun sistematis. Dokumentasi menurut Arikunto (2013:201) merupakan bukti foto yang dapat memperkuat hasil penelitian.

Teknik analisis data meliputi analisis data kualitatif dan kuantitatif. Data kualitatif berupa saran dan komentar untuk perbaikan media. Data kuantitatif berupa penilaian dalam bentuk angka. Pernyataan mengenai skala likert menurut Sugiyono (2009:135) penilaian yang diberikan berupa skor dengan kriteria (1) sangat tidak baik, (2) tidak baik, (3) baik, dan (4) sangat baik.
Analisis dibagi menjadi 2 yaitu analisis kelayakan dan kepraktisan penggunaan media. Masing-masing menggunakan perhitungan presentase yang dicontohkan oleh Sugiyono (2009:419) yaitu:

$$
\text { presentase }=\frac{\text { skor yang diperoleh }}{\text { skor yang diharapkan }} \times 100 \%
$$

Analisis kelayakan dilakukan untuk menghitung hasil validasi dari ahli materi dan ahli media. Kriteria untuk menentukan kualitas media dapat dilihat pada tabel berikut:

Tabel 1. Presentase Kelayakan

\begin{tabular}{cc}
\hline Presentase Pencapaian & Inteprestasi \\
\hline $76 \%-100 \%$ & Layak \\
\hline $56 \%-75 \%$ & Cukup Layak \\
\hline $40 \%-55 \%$ & Kurang Layak \\
\hline $0-39 \%$ & Tidak Layak \\
\hline \multicolumn{2}{c}{ (Arikunto, 2013:234) }
\end{tabular}

Analisis kepraktisan diketahui dari hasil penilaian guru dan siswa terhadap media. Kriteria penilaian dicontohkan oleh Arikunto (2009:245) dapat diketahui dari tabel berikut:

Tabel 2. Konversi Skor Respon

\begin{tabular}{cc}
\hline Presentase (\%) & Kriteria Kualitatif \\
\hline $80 \%-100 \%$ & Sangat Baik \\
\hline $66 \%-79 \%$ & Baik \\
\hline $56 \%-65 \%$ & Cukup Baik \\
\hline $40 \%-55 \%$ & Kurang Baik \\
\hline $30 \%-39 \%$ & Gagal \\
\hline
\end{tabular}

Penilaian dilakukan untuk mengetahui media pembelajaran yang dirancang baik atau harus dilakukan perbaikan. Perhitungan memiliki cara yang sama tetapi dalam perubahan nilai kuantitatif ke dalam nilai kualitatif antara analisis kelayakan dan kepraktisan berbeda. 


\section{HASIL DAN PEMBAHASAN}

\section{Hasil Pengujian Produk}

Pengujian produk dilakukan kepada ahli media, ahli materi, calon pengguna (guru), dan siswa. Tujuan dari pengujian produk dilakukan
JIP, Vol.8, No. 2, Edisi Agustus 2018, Hal: 85-94

Nury Yuniasih ${ }^{1}$, Ririn Nur Aini ${ }^{2}$, Retno Widowati ${ }^{3}$

untuk mengetahui kualitas dari media pembelajaran. Hasil dari pengujian media dapat dilihat pada tabel 3 berikut:

Tabel 3. Analisis Hasil Validasi, Penilaian guru, dan Uji Coba Terbatas

\begin{tabular}{lcccc}
\hline \multicolumn{1}{c}{ Aspek yang dinilai } & $\begin{array}{c}\text { Validasi oleh Ahli } \\
\text { Media }\end{array}$ & $\begin{array}{c}\text { Validasi oleh Ahli } \\
\text { Materi }\end{array}$ & $\begin{array}{c}\text { Penilaian dari Guru } \\
\text { sebagai Calon } \\
\text { Pengguna }\end{array}$ & $\begin{array}{c}\text { Penilaian Respon } \\
\text { Siswa }\end{array}$ \\
\hline Bahasa dan Keterbacaan & $81 \%$ & $93 \%$ & $100 \%$ & $93 \%$ \\
\hline Organisasi Penyajian & $86 \%$ & $95 \%$ & $97 \%$ & - \\
\hline Kegrafisan & $89 \%$ & - & $83 \%$ & $93 \%$ \\
\hline Isi & - & - & $\mathbf{9 3 \%}$ & $\mathbf{9 3 \%}$ \\
\hline Rata-rata Presentase & $\mathbf{8 5 \%}$ & $\mathbf{9 4 \%}$ & $\mathbf{9 1 \%}$ & \\
\hline $\begin{array}{l}\text { Rata-rata Presentase } \\
\text { Keseluruhan }\end{array}$ & & & & \\
\hline
\end{tabular}

Sumber: data diolah oleh peneliti

Berdasarkan tabel 3 telah dipaparkan hasil penilaian dari ahli media, ahli materi, guru, dan respon siswa. Penilaian dari ahli media dinilai dari 3 aspek yaitu aspek bahasa dan keterbacaan, organisasi penyajian, dan kegrafisan yang mendapatkan presentase $85 \%$ dengan kategori layak. Hal ini berarti media interaktif layak untuk digunakan. Penilaian dari ahli materi dinilai dari 2 aspek yaitu aspek bahasa dan keterbacaan, organisasi penyajian yang mendapatkan presentase 94\% dengan kategori layak. Hal ini berarti media interaktif layak untuk digunakan.

Penilaian dari calon pengguna (guru) dinilai dari 3 aspek yaitu bahasa dan keterbacaan, organisasi penyajian, serta isi mendapatkan presentase $93 \%$ dengan kategori sangat baik. Penilaian hasil respon siswa ketika dilakukan uji lapangan terbatas kepada 15 siswa dinilai dari 3 aspek yaitu bahasa dan keterbacaan, organisasi penyajian serta isi mendapatkan presentase $93 \%$ dengan kategori sangat baik. Berdasarkan penilaian di atas diketahui bahwa media interaktif berbasis Ispring sangat baik untuk digunakan ketika pembelajaran materi sistem pencernaan manusia.

\section{Pembahasan}

Prosedur pengembangan media interaktif ini mengadaptasi model pengembangan ADDIE yang dapat dipaparkan menjadi 3 aspek yaitu: a) pengembangan media interaktif berbasis Ispring, b) kelayakan media interaktif berbasis Ispring, c) kepraktisan media interaktif berbasis Ispring.

\section{Pengembangan media interaktif berbasis}

\section{Ispring}

Pengembangan media interaktif berbasis Ispring melalui 2 tahapan sesuai tahap pada model ADDIE yaitu tahap analisis dan tahap desain. Tahap analisis meliputi analisis kurikulum, karakteristik guru, karakteristik siswa, dan media dan pemanfaatannya. Hal yang didaptakan dari 
analisis kurikulum, peneliti mengetahui kurikulum yang sedang berlaku yaitu kurikulum 2013 revisi 2017. Pembelajaran telah menerapkan tematik, namun peneliti hanya fokus pada satu mata pelajaran saja yaitu IPA dengan materi sistem pencernaan manusia kelas $\mathrm{V}$ semester 1. Materi tersebut terdapat pada tema 3 (Makanan Sehat) subtema 1 (bagaimana tubuh mengolah makanan?) pembelajaran ke-5. Meskipun peneliti hanya fokus pada mata pelajaran IPA sebagai bahan pembuatan media, ketika pengujian media tetap dilakukan secara tematik.

Analisis karakteristik guru meliputi: guru lebih banyak menggunakan metode ceramah, meskipun telah menerapkan model kooperatif; guru lebih sering memperhatikan siswa yang pintar, sehingga ketika pemilihan media kurang melihat kebutuhan siswa yang heterogen; kreatifitas guru kurang dalam penggunaan media, karena guru lebih terfokus pada materi ajar.

Analisis karakteristik siswa meliputi: siswa kurang aktif, hal ini diketahui ketika guru menjelaskan siswa ramai sendiri; siswa tidak suka menghafal, siswa lebih tertarik penggunaan media dengan bantuan LCD. Analisis media dan pemanfaatannya dalam pembelajaran, media yang digunakan masih sederhana dengan menggunakan gambar, sehingga kurang mengkonkretkan materi yang abstrak.

Tahap desain yang dilakukan peneliti adalah membuat desain materi yang menunjang dibuat pada lembar kerja Microsoft Powerpoint mengenai materi, gambar, video, animasi, soal, dan kunci jawaban. Media yang dirancang peneliti lebih mudah dan menyenangkan. Peneliti juga menyediakan quiz untuk siswa yang deprogram dapat mengeluarkan skor dan pembahasan soal benar dan salah. Pada tahap ini, peneliti juga membuat instrument penelitian meliputi angket validasi ahli media, ahli materi, penilaian guru, dan respon siswa serta peneliti mengembangkan RPP sebagai pedoman implementasi.

Hal ini sejalan dengan penelitian oleh Yulia Rahmah (2017) yang melakukan pengembangan media berbasis Ispring materi sistem pernafasan. Hasil pengembangan media tersebut menghasilkan produk yang baik untuk menambah keragaman media pembelajaran dan membantu guru memberikan materi secara konkret.

\section{Kelayakan media interaktif berbasis Ispring}

Media interaktif berbasis Ispring dapat diketahui kelayakanya melalui tahap pengembangan sesuai tahapan pada model ADDIE. Tahap pengembangan yang dilakukan adalah memproduksi media dan melakukan validasi kepada ahli media dan ahli materi.

Memproduksi media yang dilakukan peneliti yaitu menambahkan media dengan animasi, background, dan interaktivitas media agar lebih menarik. Desain dari media dapat dilihat sebagai berikut:

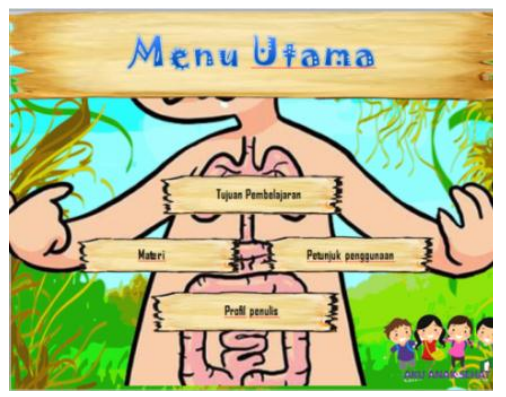




\section{Gambar 1. Halaman Menu Utama Media}

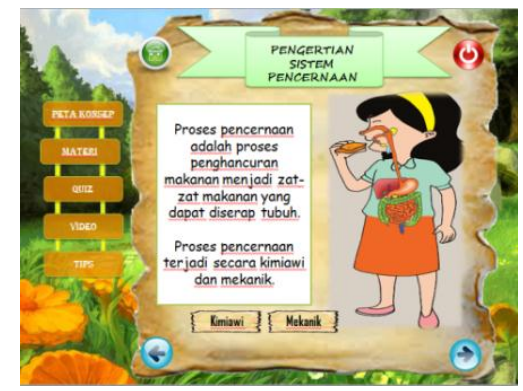

Gambar 2. Halaman Materi

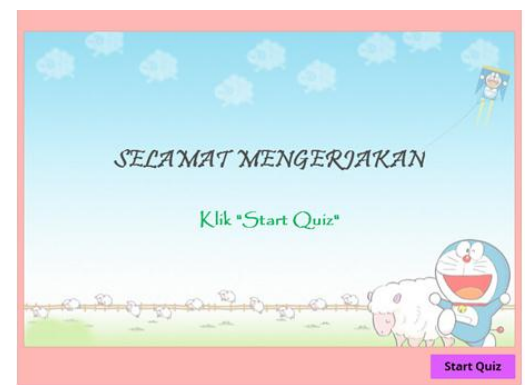

Gambar 3. Halaman Pembuka Quiz

Hasil pengembangan yang telah dilakukan maka peneliti melakukan validasi kepada ahli media dan ahli materi untuk mengetahui kelayakan pada media yang terdiri dari penilaian, saran dan komentar. Hal ini dilakukan sebagai bahan perbaikan media. Penilaian hasil validasi mendapatkan kategori layak yang dapat dilihat pada tabel. Penelitian ini sejalan yang dilakukan Maulani (2016), hasil dari validasi tersebut media pembelajaran dapat digunakan sebagai pendukung dari proses pembelajaran yang bervariasi.

\section{Kepraktisan media interaktif berbasis Ispring}

Media berbasis Ispring dapat diketahui kepraktisannya melalui tahap implementasi sesuai tahap ke 4 model pengembangan ADDIE. Hasil penilaian kepraktisan diperoleh dari calon pengguna (guru) dan siswa. Kegiatan penilaian oleh guru dilakukan sebelum implementasi kepada siswa kelas V di SDN Ciptomulyo 3 sebanyak 15
JIP, Vol.8, No. 2, Edisi Agustus 2018, Hal: 85-94 Nury Yuniasih ${ }^{1}$, Ririn Nur Aini ${ }^{2}$, Retno Widowati ${ }^{3}$

orang. Penilaian oleh guru mendapatkan presentase 93\% kategori sangat baik sehingga media dapat diimplementasikan kepada siswa. Implementasi kepada siswa dilakukan untuk mengetahui respon siswa ketika melakukan pembelajaran menggunakan media interaktif berbasis Ispring. Penilaian dari respon siswa mendapatkan presentase $93 \%$ kategori sangat baik, sehingga media dikatakan praktis dalam penggunaanya.

Hal ini sejalan dengan penelitian Ramansyah (2014) yang mengembangkan media berbasis multimedia mendapatkan kualifikasi sangat baik. Penilaian tersebut menunjukkan bahwa media baik untuk diimplementasikan dan praktis dalam pengoperasiannya oleh siswa dalam pembelajaran.

\section{PENUTUP}

Berdasarkan penelitian pengembangan media interaktif berbasis Ispring materi sistem pencernaan manusia dapat disimpulkan bahwa media interaktif dapat membantu siswa belajar dengan konkret. Media ini berisi materi yang didukung gambar, video, aniamsi, quiz dan kunci jawaaban untuk membantu siswa belajar mandiri.

Kelayakan media interaktif dapat dilihat dari penilaian ahli media dan ahli materi. Penilaian oleh ahli media mendapatkan presentase $85 \%$ kategori layak. Penilaian oleh ahli materi mendapatkan presentase $94 \%$ kategori layak. Berdasarkan penilaian tersebut media layak untuk diimplementasikan.

Kepraktisan media interaktif diketahui dari hasil penilaian oleh calon pengguna (guru), dan 
respon siswa. Penilaian oleh guru mendapatkan presentase 93\% kategori sangat baik. Penilaian dari respon siswa mendapatkan kategori 93\% kategori sangat baik. Berdasarkan penilaian tersebut media interaktif sangat baik dan praktis digunakan sebagai media pembelajaran.

Saran peneliti untuk guru, media interaktif dapat digunakan sebagai alat bantu dalam kegiatan pembelajaran agar materi sistem pencernaan manusia lebih konkret. Saran bagi siswa yaitu produk ini dapat dijadikan sebagai bahan ajar mandiri di rumah maupun saat pembelajaran berlangsung. Bagi peneliti lain, dapat dijadikan referensi dalam mengembangkan media pembelajaran yang sejenis dan lebih kreatif.

\section{DAFTAR PUSTAKA}

Agustin, Mubiar. 2011. Permasalahan Belajar dan Inovasi Pembelajaran Panduan untuk Guru, Konselor, Psikolog, Orang Tua, dan Tenaga Kependidikan. Bandung: PT Refika Aditama

Arikunto, Suharsini. 2009. Dasar-dasar Evaluasi Pendidikan. Jakarta: Bumi Aksara

Arikunto, Suharsini. 2013. Prosedur Penelitian. Jakarta: Rineka Cipta

Darmawan, Deni. 2015. Komunikasi Pendidikan Perspektif Bio-komunikasi. Bandung: Remaja Rosdakarya

Fathurrohman, Pupuh \& Sutikno, Sobry. 2014. Strategi Belajar Mengajar. Bandung: PT Refika Aditama

Gafur, Abdul. 2012. Desain Pembelajaran. Yogyakarta: Ombak Dua

Hernawati, Kuswati. 2010. Modul Pelatihan Ispring Presenter. Modul (online), (http:/stafnew.uny.ac.id/uploud/132309677/p engabdian/modul-ispring-presenter.pdf)

Indriana, Dina. 2011. Ragam Alat Bantu Media Pembelajaran. Yogyakarta: Diva Press

Maulani Putri, Wenggita. 2016. Pengembangan Media Pembelajaran Berbasis Multimedia Augmented Reality pada Pokok Bahasan Alat
JIP, Vol.8, No. 2, Edisi Agustus 2018, Hal: 85-94 Nury Yuniasih ${ }^{1}$, Ririn Nur Aini ${ }^{2}$, Retno Widowati ${ }^{3}$

Optik. Jurnal Ilmu Pendidikan, 5(1), 3-5. (http:/www.researchgate.net)

Prastowo, andi. 2011. Panduan Kreatif Membuat Bahan Ajar Inovatif. Yogyakarta: Diva Press

Rizema Putra, Sitiatava. 2013. Desain Belajar Mengajar Kreatif Berbasis Sains. Yogyakarta: Diva Press

Ramansyah, Wanda. 2014. Pengembangan Multimedia Pembelajaran Interaktif Berbasis Adobe Flash CS3 pada Kelas 1 SDN Bancaran 3 Bangkalan. Jurnal Ilmu Pendidikan, 1(1), 4-9. (http:/download.portugalgaruda.org)

Rusman, dkk. 2012. Pembelajaran Berbasis Teknologi Informasi dan Komunikasi. Jakarta: PT RajaGrafindo Persada

Sanjaya, Wina. 2012. Media Komunikasi Pembelajaran. Jakarta: Prenadamedia Group Sugiyono. 2009. Metode Penelitian Pendidikan. Bandung: Alfabeta

Sugiyono. 2010. Metode Penelitian Pendidikan. Bandung: Alfabeta

Sugiyono. 2012. Metode Penelitian Kombinasi (Mixed Methods). Bandung: Alfabeta

Susanto, Ahmad. 2013. Teori Belajar dan Pembelajaran di Sekolah Dasar. Jakarta: Prenadamedia Group

Suyanto, dan Jihad, Asep. 2013. Menjadi Guru Profesional Strategi Meningkatkan Kualifikasi Guru di era Global. Jakarta: Erlangga

Widoyoko. 2013. Evaluasi Program Pembelajaran. Yogyakarta: Puataka Pelajar

Winarno. 2009. Teknik Evaluasi Multimedia Pembelajaran. Yogyakarta: Genius Prima Media

Yulia Rahmah, Devi. 2017. Pengembangan Media Interaktif Berbasis Ispring untuk Peningkatan Hasil Belajar Siswa Kelas V di Madrasah Ibtidaiyah Negeri Loloan Timur Jembrana Bali. Skripsi tidak diterbitkan. Malang: FIP Universitas Islam Negeri Maulana Malik Ibrahim. 